\title{
The Role of Percutaneous Drainage in the Treatment of Severe Acute Pancreatitis on the Basis of the Modified Atlanta Classification
}

\author{
Zsolt Szentkereszty, Róbert Kotán and Péter Sápy \\ University of Debrecen, Medical Health Science Center, Institute of Surgery, \\ Hungary
}

\section{Introduction}

According to the Atlanta Classification in many cases of acute pancreatitis there are three well-defined fluid collections: acute peripancreatic fluid collection (APFC), the so-called postnecrotic pancreatic/peripancreatic fluid collection which develops in the region of liquified pancreatic necrosis, and the pseudocyst that develops in the late phase of the illness.

In many cases, these anatomic entities can be succesfully treated with radiological interventional methods.

It is difficult to correctly interpret the articles that review the treatment of numerous patients because the nomenclature is unclear. The aim of this article is to analyse the indications, limits and results of the listed complications treated by percutaneous drainage (PD) which aggravate acute pancreatitis on the basis of the literature.

\section{What to drain?}

\subsection{Acute peripancreatic fluid collection (APFC)}

According to the Atlanta Classification peripancreatic fluid collection develops in the early phase of acute pancreatitis in about $40 \%$ of cases. The acute fluid collection usually develops around the pancreas but sometimes emerges in the glandular area and does not contain a high quantity of necrosis. Not rarely, it spreads into the chest, mediastinum and/or into the pararenal area. Several fluid collections can develop at the same time and can shuttle together. The rich pancreatic enzyme content of the fluid can indicate communication with the pancreatic duct or indicate parenchymal necrosis. They do not have definite walls, and are limited by the walls of the surrounding organs. In a significant number of cases (about $30-50 \%$ ), spontaneous resolution occurs without surgical or other intervention. If they do not show tendency towards resolution, they can become of significant size and cause clinical symptoms or complications [5,6,33,44].

The most frequent complaints caused by a big, $8-15 \mathrm{~cm}$ size acute fluid collection are pain, tension, and increasing abdominal pressure which can significantly worsen the efficiency of breathing [1,9]. In other cases they can cause compression symptoms (jaundice, duodenal obstruction) or bleeding can develop inside of them. Another frequent complication is the 
superinfection of the fluid that can be confirmed by fine needle aspiration (FNA) $[1,2,11,19,25,33,37,40,44]$.

The APFC can be visualized by CT scan or ultrasound examination as well. The number of acute fluid collections correlate to the severity of the pancreatitis, the length of hospitalization and mortality [19].

Even today the treatment of acute peripancreatic fluid collections is not totally clear. In a small sized fluid collection, conservative treatment (naso-jejunal feeding, the resting of pancreas) is usually effective. Fluid evacuation is advisable when it causes severe symptoms. In the past only surgical intervention was available. The authors do not recommend surgical treatment in the early phase of the illness because of the high morbidity and mortality rates. With the development of interventional radiology and manipulative laparo-endoscopy there are other possibilities to evacuate these fluid collections without operation $[1,6,11,14,21,25,35,40,44]$.

For the treatment of sterile fluid collection percutaneous puncture and drainage are widely applied. It is disputed whether repeated punctures or drainage is the most suitable for the treatment of fluid collections. There are some who are satisfied with the clearing of the fluid collection with only one or repeated punctures in sterile cases. However, this is succesful only in a few cases and drainage or surgical intervention follows $[6,28,40,44]$.

According to those who are pro drainage in the treatment of sterile acute peripancreatic fluid collections, drainage can be applied effectively [1,3,4,14,21,25,34,35,40,44]. Acute compartment syndrome caused by massive acute peripancreatic fliud collection can be treated effectively with PD [9]. In the randomized controlled trial of Zerem et al. they commit themselves to drainage treatment [44].

Those who are against drainage treatment claim that it is the treatment itself which causes the dreadful complication, the infection of the fluid. According to the literature the rate of iatrogenous infection is about $8-27 \%[12,25,28,40]$. Walser, Zerem et al. report a very high, $50 \%$ rate of infection which is, in our opinion, the result of the irrigation 2-3 times a day $[40,44]$. To determine the correct rate of iatregenous infections treated without drainage or puncture a prospective randomized trial should be performed which is not available at this time.

With regard to the management of infected acute peripancreatic fluid collections, views are not as varied in these cases: percutaneous drainage is suggested [1,5,8,18,21,22,25,33,34].

Surgery can often be avoided by drainage treatment, and in other cases the intervention is suitable for delaying operative treatment. In such cases, when drainage is not effective, operation is suggested $[5,6,8,18,21,22,25,34,35,44]$.

\subsection{Post-necrotic Pancreatic Fluid Collection (PNPFC), Walled-off Pancreatic Necrosis (WOPN)}

Necrosis can liquify and can be accompanied by the development of different sizes of fluid collections. These cases are equivalent to the pathological entity accepted in the modified Atlanta Classification as postnecrotic peripancreatic/pancreatic fluid collection and walledoff pancreatic necrosis. WOPN can be misdiagnosed by contrast-enhanced CT for pseudocyst but MRI, abdominal or endoscopic ultrasound can help with differential diagnosis for these are suitable for proving the significant quantity of necrosis in the fluid. This differentiation is very important because treatment, especially the minimally invasive one, is different because in cases of WOPN the necrotized tissues should be removed. PNPFC cases can be sterile and infected as well $[5,12,18,22,24,33,34,43]$. 
In cases of PNFC puncture and/or drainage is usually not enough, the evacuation of necrotic tissues are also necessary and for this reason some authors are explicitely against drainage treatment $[3,6,22]$. According to other authors the evacuation of necrosis and fluid collection is possible with the help of irrigation through 14-30 F bore drains. Necrosectomy can be performed by using dormia basket. For such treatment more catheters should be placed in the cavity $[5,10,11,12,18,21,26,29,33,36,38,43]$. Bruennel et al. did not find a relation between the thickness, or the number of the drains and the effectiveness. With so-called 'sinus tract endoscopy' necrectomy can be performed effectively following the dilatation of the drain's channel $[23,36,43]$. Horvath et al. performed necrosectomy via the channels of the drains with a supplementary incision using laparoscopy [16,17].

More than $20 \%$ of the patients treated with the minimal invasive method recovered without operation. An alternative method for the treatment of WOPN is the endoscopic transmural necrosectomy and drainage [13,15,27,30,31,41]. Necrosectomy during operation is the suitable method in cases of unsuccessfully treated patients $[3,6,10,11,12,22,24,26,28$, $33,34,36,43]$.

\subsection{Acute pseudocyst}

The acute pseudocyst appears on CT scan as a walled, oval or circle shaped fluid. It often develops in the area of an earlier acute fluid collection which did not show any tendency to resolution. The frequency of this is about $30-50 \%$. The wall of the pseudocyst contains inflammatory tissues but is not covered by epithelium. It develops most frequently in the environment of the pancreas but mediastinal or pelvic appearances are also known. About 4 weeks are needed for the development of the mutation from the beginning of the disease. Its content is usually sterile but sometimes bacteria can be detected without any clinical manifestation, in other cases it contains pus [5].

Almost $50 \%$ of acute pseudocysts do not cause any clinical symptoms and show spontaneous absorbing susceptibility. Especially smaller pseudocysts that are not bigger than 4-6 cm, recover with conservative treatment (eg: naso-jejunal feeding) [18,33,37]. Bigger pseudocysts can cause explicit clinical complaints. Compressive symptoms and pain are the most frequent among them. As a complication the content can become infected. Air bubbles can be seen in it on CT examination. In its cavity pseudoaneurysm can develop which can cause fatal bleeding $[2,6,11,14,28,33,37]$.

In those cases where compressive or respiratory complications or pain develop, surgery or less burdensome percutaneous drainage gives an opportunity for treatment, allowing for the descent of the fluid as well as its bacterological examination [3,4,6,8,11,18,24,33,35]. More drains can be placed in cases of multiple pseudocysts [11,18,35]

Operation can be avoided in cases treated this way and drainage can lead to complete recovery, in other cases it is suitable for delaying the time of operation $[3,4,6,8,11,18,37,43]$. In those cases where the cyst cavity communicates with the Wirsung ductal system, external drainage is not effective. For this reason, the anatomical conditions of the pseudocyst must be cleared by ERCP prior to external drainage [18]. In cases when communication is detected between the pancreatic duct and the necroma as a well accepted method internal endoscopic transluminal drainage (NOTES) and lavage, with endoscopic necrosectomy is indicated $[13,30]$.

The infected pseudocyst appears as a pancreatic abscess in the late phase of severe acute pancreatitis, at least 4 weeks after the beginning of the disease and needs radiologic 
intervention or surgery in each case. It does not contain a considerable quantity of necrotic tissue mass in opposition to the infected liquified necrosis (Post-necrotic Pancreatic Fluid Collection, Walled-off Pancreatic Necrosis). On CT scan gas bubbles can be observed $[1,2,5,6,18,20,29,37,43]$.

Surgery in these cases involves a lower rate of morbidity and mortality than those performed in the early phase of pancreatitis. The results are good [20,37]. Percutaneous drainage treatment can be applied in cases of pancreatic abscess with good results and it can be suggested as the first intervention $[4,5,6,8,18,20,29,33,37,38,43]$. Drainage can be also applied in cases of numerous abscesses. It is important to carry out bacterological analysis from each abscess one by one because different types of bacteria can be cultured from them. The management must be supplemented with antibiotics $[1,4,5,18,20,26]$.

PD has an effectiveness of $31-94 \%$ in the treatment of pancreatic abscesses $[1,4,5$, $8,18,20,26,33,37,43]$.

\section{How to drain?}

For drainage a pig-tail catheter is well accepted. The insertion of the drain can be guided by CT or ultrasound and fluoroscopy or without it $[5,6,8,10,11,12,18,21,28,32,39,42,44]$. The catheter with the main wire is led into the fluid collection and following verification of its placement the wire is removed (Figure 1-2). The indication of the location and function is that a proper quantity of fluid appears. Depending on the quality of the fluid, different size of drains should be used. If there is an abscess, the thicker (14-30F), otherwise the thinner (8$10 \mathrm{~F})$, pig-tail catheter is to be used $[1,6,8,10,11,12,21,32,36,39]$. The drained fluid shlould be sent for bacterological analysis in each case. More drains can be inserted at a time if necessary $[5,8,10,11,12,18,21,32,33,35,39,42,44]$.

The drain is usually placed without active suction. The daily quantity and quality of the fluid must be measured and examined. If the sterile fluid becomes thickened or purulent, it signifies bacterial infection. If pus appears or the fluid is dense, the irrigation of the cavity is also possible $[1,10,11,21,42,44]$.

Ultrasound examination is the most suitable for the observation of the size of the fluid collection. It is also inexpensive and can also be performed bedside (Figure 3). The cavity filled with contrast material can be well demonstrated and is apt for showing fistulae $[1,6,10,11,42,44]$.

The drain can be removed if the fluid has cleared up, has become "sterile", the quantity of the drained fluid is less than $10-30 \mathrm{ml}$ per day and the cavity has deflated on imaging examinations $[1,6,10,12,44]$.

More than $20 \%$ of patients $(20-50 \%)$ recover without surgery, by drainage treatment. If the drained cavity does not decrease during drainage or the septic state does not show a tendency towards resolution, surgical treatment is indicated. In such cases with the application of drainage early operation can be avoided [1,4,6,8,10,11,12,21,26,32,35,39,42]. Others suggest transluminal endoscopic (NOTES) procedure if percuteanous drainage is failed $[7,13,15,27,30,31,41]$ Some authors suggest the combination of external and internal drainage with endoscpopic necrosectomy [27,30,].

Complications related to percutaneous drainage are rare. In an experienced hand the rate of iatrogenic injuries are negligible, less than $2 \%$, generally the injury of the surrounding organs, bleeding can be noticed $[1,4,11,12,21,32,35,39,44$,$] . Sometimes the drain can get$ clogged or slip out, then its replacement is required $[8,35,42,44]$. 


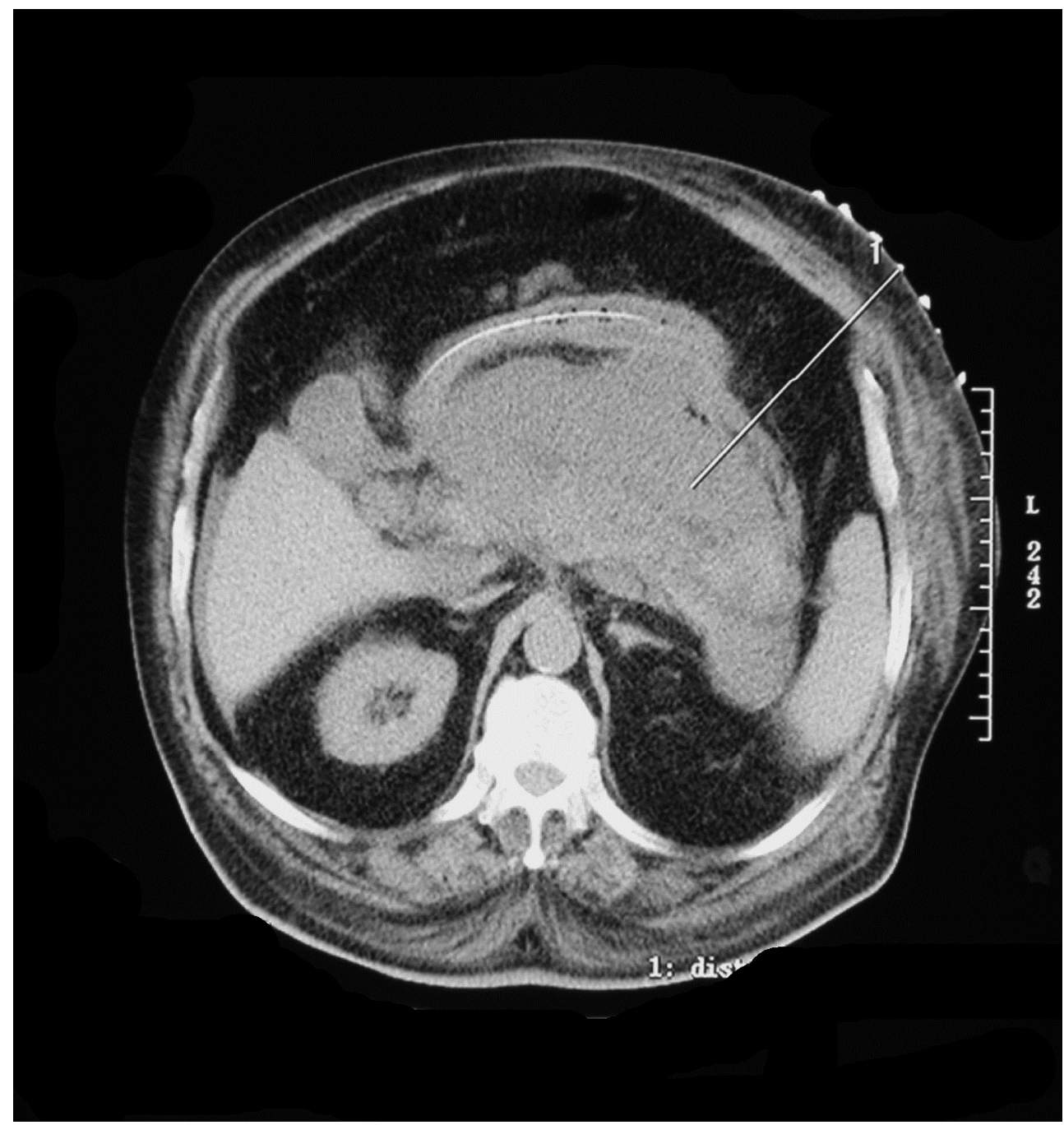

Fig. 1. Percutaneous CT guided puncture of acute peripancreatic fluid collection

A late complication of PD is the development of pancreatic fistulae, which may be in relation with the skin or gastrointestinal tract and most close spontaneously. The facts that influence the effectiveness of PD of infected fluid collections positively are the presence of a single fluid collection, the lack of necrosis, the low APACHE-II and Ransome points and the lack of failure $[8,35,42,44]$.

In this chapter the authors suggest reviewing the transmural endoscopic (NOTES) necrosectomy as a minimal invasive method. More and more authors in selected patients use this method for necrosectomy with a successful rate of $73-92 \%[2,7,13,15,27,30,31,41]$. The necrotic cavity can be drained to the stomach or the duodenum. The effectiveness of this method can be enhanced with the use of endoscopic ultrasound (ES) $[7,13,15,27,30,31,41]$. 
After dilating the puncture chanel to $8-20 \mathrm{~mm}$ the necrectomy can be performed with the use of baskets, snares, transparent scope caps, nets and/or water jet $[7,13,27,30,31,41]$. This procedure must be repeated till the complete emptying of the necroma $[7,13,27,30,31]$. After the necrectomy it is essential to drain the cavity with pigtail catheters, or stents $[13,41]$. The endoscopic drainage of WOPN decreases the length of hospitalization, the duration of external drainage, the number of CT scans [15]. This method is a possible therapy before or instead of surgery $[2,7,13,27,30,31,41]$.

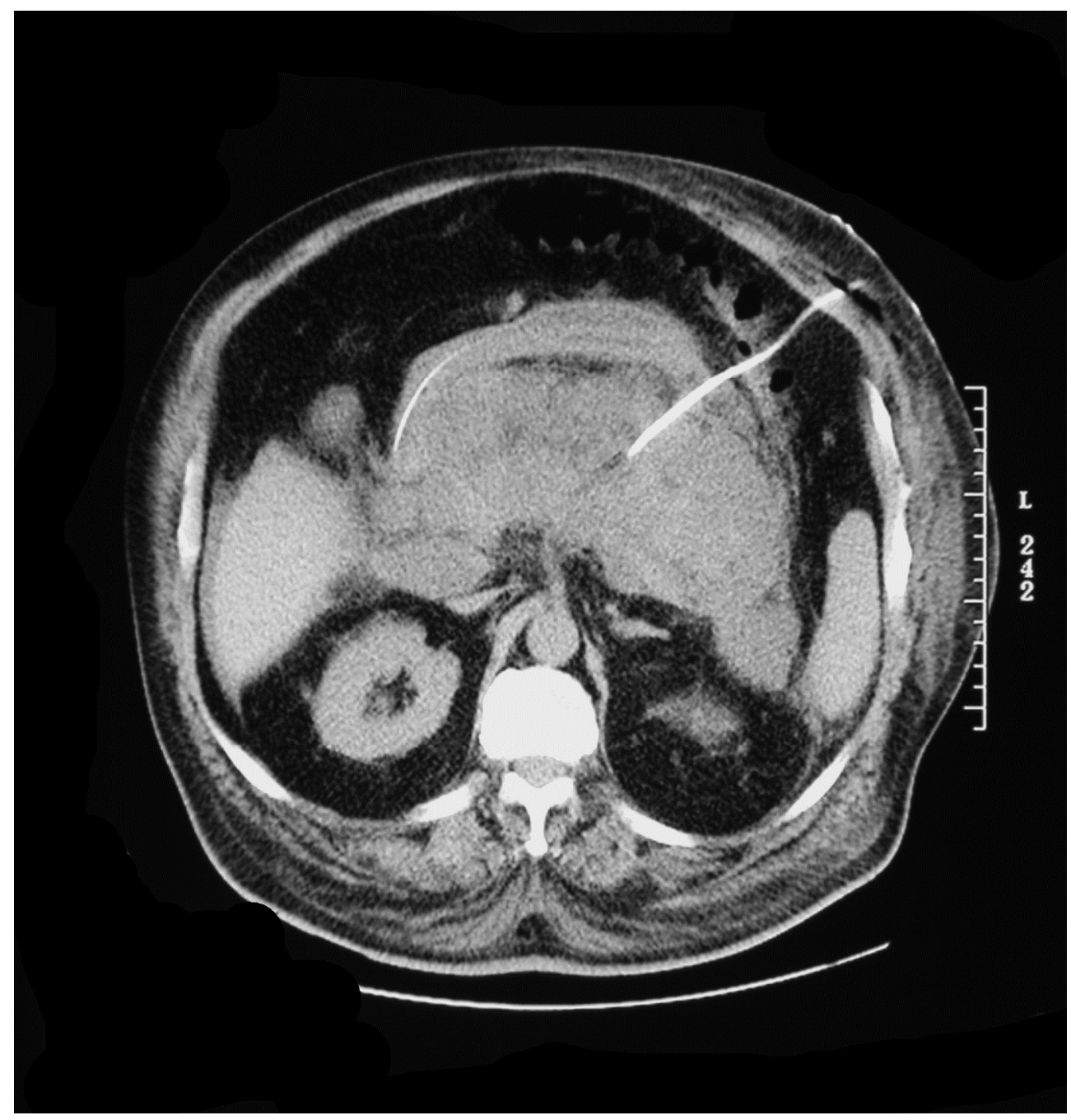

Fig. 2. Percutaneous CT-guided drainage of acute peripancreatic fluid collection 


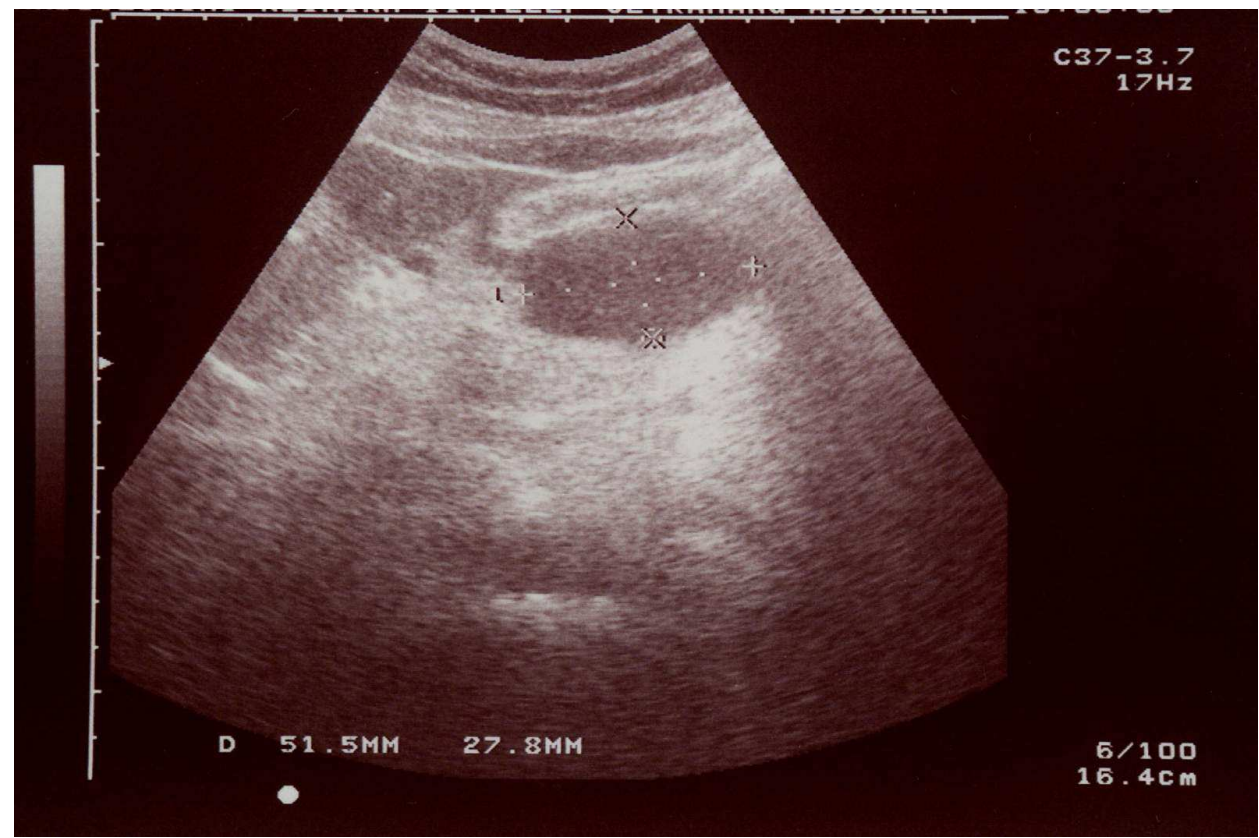

Fig. 3. Ultrasound wiew of drainaged acute peripancreatic fluid collection

In conclusion percutaneous drainage plays an important role in the treatment of concomitant sterile ad septic fluid collections (APFC, PNPFC, WOPN, acute pseudocyst) in severe acute pancreatitis. In well selected cases percutaneous drainage with appropriate caliber drains and supplementary therapy in the greater part of cases leads to complete recovery. In other cases PD is useful to delay surgery or to avoid early operation.

\section{Abbreviations}

APFC: Acute Peripancreatic Fluid Collection

PD: Percutaneous Drainage

FNA: Fine Needle Aspiration

CT: Computed Tomography

PNPFC: Post-necrotic Pancreatic Fluid Collection

WOPN: Walled-off Pancreatic Necrosis

MRI: Magnetic Resonance Image

ERCP: Endoscopic Retrograde Cholangio-Panreatographia

ES: Endoscopic Ultrasound

NOTES: Natural Orifice Transluminal Endoscopic Surgery

\section{References}

[1] Ai X, Qian X, Pan W, Xu J, Hu W, Terai T, Sato N, Watanabe S: Ultrasound-guided percutaneous drainage may decrease the mortality of severe acute pancreatitis. J Gastroenterol 2010, 45, 77-85. 
[2] Amano H, Takada T, Isaji S, Takeyama Y, Hirata K, et al.: Therapeutic intervention and surgery of acute pancreatitis. J Hepatobiliary Pancreat Sci 2010, 17, 53-9.

[3] Aultman DF, Bilton BD, Zibari GB, McMillan RW, McDonalds JC: Nonoperative therapy for acute necrotizing pancreatitis. Am Surg 1997, 63, 1114-1117.

[4] Baril NB, Ralls SM, Selby RR, Radin R., Parekh D, Jabbour N, et al.: Does infected peripancreatic fluid collection or abscess mandate operation? Ann Surg 2000, 231, 361-367.

[5] Bruennler T, Langgartner J, Lang S, Wrede CE, Klebl F, Zierhut S, et al:: Outcome of patients with acute, necrotizing pancreatitis requiring drainage-does drainage size matter? W J Gastroenterol 2008, 14, 725-730.

[6] Chalmers AG: The role of imaging in acute pancreatitis. Eur. J. Gastro. Hepatol 1997, 9, 106-116.

[7] Charnley RM, Lochan R, Gray H, O'Sullivan CB, Scott J, et al.: Endoscopic necrosectomy as primary therapy in the management of infected pancreatic necrosis. Endoscopy 2006, 38, 925-8.

[8] Chen YF, Chiang HJ, Chang JH.: Abdominal fluid collection secondary to acute pancreatitis: treated with percutaneous cathater drainage. Chin Med J 1997, 60, 26572.

[9] Dambrauskas Z, Parseliūnas A, Maleckas A, Gulbinas A, Barauskas G, Pundzius J: Interventional and surgical management of abdominal compartment syndrome in severe acute pancreatitis. Medicina (Kaunas) 2010, 46, 249-255.

[10] Echenique AM, Sleeman D, Yrizzary J, et al.: Percutaneous catheter-directed debridement of infected pancreatic necrosis: Results in 20 patients. J Vasc Interv Radiol 1998, 9, 565-571.

[11] Fotoohi M, D'Agostino HB, Wollman B, Chon K, Shahrokni S, van Sonnenberg E: Persistent pancreatocutaneous fistula after percutaneous drainage of pancreatic fluid collections: role of cause and severity of pancreatitis. Radiology 1999, 213, 573578.

[12] Freeny PC, Hauptmann E, Althaus SJ, Traverso LW, Sinanan M: Percutaneous CTguided catheter drainage of infected acute necrotizing pancreatitis: techniques and results. Am J Roengennol 1998, 170, 969-975.

[13] Friedland S, Kaltenbach T, Sugimoto M, Soetikno R.: Endoscopic necrosectomy of organized pancreatic necrosis: a currently practiced NOTES procedure. J Hepatobiliary Pancreat Surg 2009, 16, 266-9.

[14] Gambiez LP, Denimal FA, Porte HL, Saudemont A, Chambon J-PM, Quandalle PA: Retroperitoneal approach and endoscopic management of peripancreatic necrosis collections. Arch Surg 1998, 133, 66-72.

[15] Gluck M, Ross A, Irani S, Lin O, Hauptmann E, Siegal J, Fotoohi M, Crane R, Robinson D, Kozarek RA.: Endoscopic and percutaneous drainage of symptomatic walled-off pancreatic necrosis reduces hospital stay and radiographic resources. Clin Gastroenterol Hepatol 2010, 8, 1083-8.

[16] Horvath KD, Kao LS, Ali A, Wherry K.L, Pellegrini CA, Sinanan MN: Laparoscopic assisted percutaneous drainage of infected pancreatic necrosis. Surg Endosc 2001, $15,677-682$. 
[17] Horvath KD, Kao LS, Wherry KL, Pellegrini CA, Sinanan MN: A technique for laparoscopic-assisted percutaneous drainage of infected pancreatic necrosis and abscess. Surg Endosc 2001, 15, 1221-1225.

[18] Loveday BP, Mittal A, Phillips A, Windsor JA: Minimally invasive management of pancreatic abscess, pseudocyst, and necrosis: A systematic review of current guidlines. W J Surg 2008, 32, 2383-2394.

[19] Luo Y, Yuan CX, Peng YL, Wei PL, Zhang ZD, Jiang JM, et al.: Can ultrasound predict severity of acute pancreatitis early by observing acute fluid collection. World J Gastroenterol 2001, 7, 293-295.

[20] Mithöfer K., Mueller P.R., Warshaw A.L.: Interventional and surgical treatment of pancreatic abscess. World J Surg 1997, 21, 162-168.

[21] Mortelé KJ, Girshman J, Szejnfeld D, Ashley SW, Erturk SM, Banks PA, Silverman SG: CT-guided percutaneous catheter drainage of acute necrotizing pancreatitis: clinical experience and observations in patients with sterile and infected necrosis. AJR Am J Roentgenol 2009, 192, 110-6.

[22] Mueller PR.: Percutaneous drainage of pancreatic necrosis: Is it ecstasy or agony? Am J Roengennol 1998, 170, 976-977.

[23] Mui LM, Wong SK, Ng EK, Chan AC, Chung SC: Combined sinus tract endoscopy and endoscopic retrograde cholangiopancreatography in management of pancreatic necrosis and abscess. Surg Endosc 2005, 19, 393-397.

[24] Navalho M, Pires F, Duarte A, Gonçalves A, Alexandrino P, Távora I: Percutaneous drainage of infected pancreatic fluid collections in critically ill patients: Correlation with C-reactive protein values. J Clin Imaging 2006, 30, 114-119.

[25] Nealon WH, Bawduniak J, Walser EM.: Appropriate timing of cholecystectomy in patients who present with moderate to severe gallstone-associated acute panreatitis with peripancreatic fluid collections. Ann Surg 2004, 239, 741-749.

[26] Oláh A, Balágyi T, Bartek P, Pohárnok L, Romics L jr: Alternative treatment modalities of infected pancreatic necrosis. Hepato-Gastroenterol 2006, 53, 603-607.

[27] Papachristou GI, Takahashi N, Chahal P, Sarr MG, Baron TH.: Peroral endoscopic drainage/debridement of walled-off pancreatic necrosis. Ann Surg 2007, 245, 94351.

[28] Paye F, Rotman N, Radier C, Nouira R, Fagniez PL: Percutaneous aspiration for bacteriological studies in patients with necrotizing pancreatitis. Br J Surg 1998, 85, 755-759.

[29] Pezzilli R, Zerbi A, Di Carlo V, Bassi C, Delle Fave GF; Working Group of the Italian Association for the Study of the Pancreas on Acute Pancreatitis.: Practical guidelines for acute pancreatitis. Pancreatology 2010, 10, 523-35.

[30] Ross A, Gluck M, Irani S, Hauptmann E, Fotoohi M, et al.: Combined endoscopic and percutaneous drainage of organized pancreatic necrosis. Gastrointest Endosc 2010, 71, 79-84.

[31] Seewald S, Groth S, Omar S, Imazu H, Seitz U, et al.: Aggressive endoscopic therapy for pancreatic necrosis and pancreatic abscess: a new safe and effective treatment algorithm (videos). Gastrointest Endosc 2005, 62, 92-100.

[32] Segal D, Mortele KJ, Banks PA, Silverman SG.: Acute necrotizing pancreatitis: role of CT-guided percutaneous catheter drainage. Abdom Imaging 2007, 32, 351-361. 
[33] Shankar S, vanSonnenberg E, Silverman SG, Tuncali K, Banks PA: Imaging and percutaneous management of acute complicated pancreatitis. Cardiovasc Intervent Radiol 2004, 27, 567-580.

[34] Stamatakos M, Stefanaki C, Kontzoglou K, Stergiopoulos S, Giannopoulos G, et al: Walled-off pancreatic necrosis. World J Gastroenterol 2010, 14, 1707-1712.

[35] Szentkereszty Zs, Kerekes L, Hallay J, Czako D, Sápy: CT guided percutaneous peripancreatic drainage: a possible therapy in acute necrotizing pancreatitis. Hepato-Gastroenterol 2002, 49, 1696-1698.

[36] Tang LJ, Wang T, Cui JF, Zhang BY, Li S, Li DX, Zhou S: Percutaneous catheter drainage in combination with choledochoscope-guided debridement in treatment of peripancreatic infection. World J Gastroenterol 2010, 16, 513-517.

[37] Tsiotos GG, Sarr MG.: Management of fluid collections nad necrosis in acute pancreatitis. Curr Gastroenterol Rep 1999, 1, 87-88.

[38] Uomo G.: Classical, minimally invasive necrosectomy or percutaneous drainage in acute necrotizing pancreatitis. Does changing the order of the factors change the result? JOP 2010, 11, 415-417.

[39] van Baal MC, van Santvoort HC, Bollen TL, Bakker OJ, Besselink MG, Gooszen HG; Dutch Pancreatitis Study Group.: Systematic review of percutaneous catheter drainage as primary treatment for necrotizing pancreatitis Br J Surg 2011, 98, 18-27.

[40] Walser EM, Nealon WH, Marroquin S, Raza S, Hernandez JA, Vasek J: Sterile fluid collections in scute pancreatitis: Catheter drainage versus simple aspiration. Cardiovasc. Intervent Radiol, 2006, 29, 102-107.

[41] Wehrmann T, Martchenko K, Riphaus A.: Dual access endoscopic necrosectomy of infected pancreatic necrosis: a case report. Eur J Gastroenterol Hepatol 2010, 22, 237-40.

[42] Wig JD, Gupta V, Kocchar R, Doley RP, Yadav TD, Poornachandra K S, et al.: The role of non-operative strategies in the management of severe acute pancreatitis. JOP 2010, 11, 553-559.

[43] Wysocki AP, McKay CJ, Carter CR: Infected pancreatic necrosis: minimizing the cut. ANZ J Surg 2010, 80, 58-70.

[44] Zerem E, Imamovic G, Omerović S, Imširović B.: Randomized controlled trial on sterile fluid collections management in acute pancreatitis: Should they removed? Surg Endosc 2009, May 15. [Epub ahead of print] 


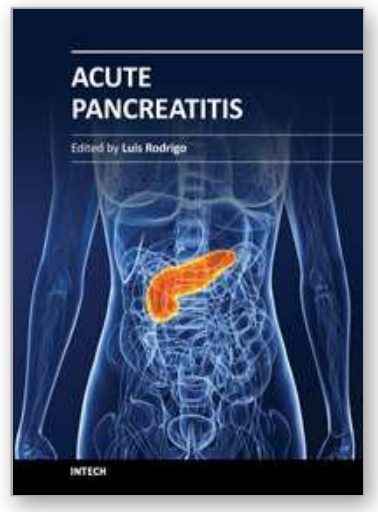

\author{
Acute Pancreatitis \\ Edited by Prof. Luis Rodrigo
}

ISBN 978-953-307-984-4

Hard cover, 300 pages

Publisher InTech

Published online 18, January, 2012

Published in print edition January, 2012

Acute Pancreatitis (AP) in approximately $80 \%$ of cases, occurs as a secondary complication related to gallstone disease and alcohol misuse. However there are several other different causes that produce it such as metabolism, genetics, autoimmunity, post-ERCP, and trauma for example... This disease is commonly associated with the sudden onset of upper abdominal pain that is usually severe enough to warrant the patient seeking urgent medical attention. Overall, $10-25 \%$ of AP episodes are classified as severe. This leads to an associated mortality rate of $7-30 \%$ that has not changed in recent years. Treatment is conservative and generally performed by experienced teams often in ICUs. Although most cases of acute pancreatitis are uncomplicated and resolve spontaneously, the presence of complications has a significant prognostic importance. Necrosis, hemorrhage, and infection convey up to $25 \%, 50 \%$, and $80 \%$ mortality, respectively. Other complications such as pseudocyst formation, pseudo-aneurysm formation, or venous thrombosis, increase morbidity and mortality to a lesser degree. The presence of pancreatic infection must be avoided.

\title{
How to reference
}

In order to correctly reference this scholarly work, feel free to copy and paste the following:

Zsolt Szentkereszty, Róbert Kotán and Péter Sápy (2012). The Role of Percutaneous Drainage in the Treatment of Severe Acute Pancreatitis on the Basis of the Modified Atlanta Classification, Acute Pancreatitis, Prof. Luis Rodrigo (Ed.), ISBN: 978-953-307-984-4, InTech, Available from:

http://www.intechopen.com/books/acute-pancreatitis/the-role-of-percutaneous-drainage-in-the-treatment-ofsevere-acute-pancreatitis-on-the-basis-of-the-

\section{INTECH}

open science | open minds

\section{InTech Europe}

University Campus STeP Ri

Slavka Krautzeka 83/A

51000 Rijeka, Croatia

Phone: +385 (51) 770447

Fax: +385 (51) 686166

www.intechopen.com

\section{InTech China}

Unit 405, Office Block, Hotel Equatorial Shanghai

No.65, Yan An Road (West), Shanghai, 200040, China 中国上海市延安西路65号上海国际贵都大饭店办公楼 405 单元

Phone: +86-21-62489820

Fax: +86-21-62489821 
(C) 2012 The Author(s). Licensee IntechOpen. This is an open access article distributed under the terms of the Creative Commons Attribution 3.0 License, which permits unrestricted use, distribution, and reproduction in any medium, provided the original work is properly cited. 